\title{
AMINOTRIPEPTIDASE CONTENT OF SYNOVIAL FLUID IN ARTHRITIC DISEASES ${ }^{1}$
}

\author{
BY MORRIS ZIFF, JEROME SIMSON, EDWARD SCULL,2 ALFRED SMITH, \\ JENNIE SHATTON, AND DONALD MAINLAND \\ (From the Study Group on Rheumatic Diseases, and the Departments of Medicine and Medical \\ Statistics, New York University-Bellevue Medical Center, New York, N. Y.)
}

(Submitted for publication July 21, 1954; accepted September 3, 1954)

When an inflammatory reaction is present in the lining membrane of a fluid-containing body space, the dissolution of the inflammatory cells present in the membrane and fluid releases into the effusion the enzymes contained in these cells. The concentration of enzyme present in the fluid at any given time should be related to the degree of inflammation and might, therefore, serve as a measure of this change. The requirements for the enzyme to be chosen to measure inflammation in this way are that it should be stable, that its activity should be easily determined, and that it should be present in high concentration in leucocytes.

Aminotripeptidase is an enzyme which has been shown by Ellis and Fruton, and by Smith, to be widely distributed in tissues and to be especially richly concentrated in leucocytes $(1,2)$. It is stable and may be determined by measuring the rate of hydrolysis of an aminotripeptide, such as glycylglycylglycine.

Aminotripeptidase has been shown to be present in human serum by Grassmann and Heyde (3). Its concentration shows little variation in the serum of normal human adults, but is increased in certain pathological states (4), including bone fracture (5). Schwartz and Engel (6) observed moderately increased levels of aminotripeptidase activity in the serum of patients with rheumatic fever, which were reduced on administration of corticotropin.

The degree of synovial inflammation is usually measured by the leucocyte conterit of the synovial fluid. Leucocyte counts in synovial effusions, however, are variable and often rendered inaccurate by the presence of particulate matter. A more accurate and consistent measure of synovial

\footnotetext{
1 This work was supported in part by the Masonic Foundation for Medical Research and Human Welfare, and in part by the Squibb Institute for Medical Research.

2 Present Address : Hartford Hospital, Hartford, Conn.
}

inflammation is, therefore, desirable and a previous report by Ziff, Scull, Ford, McEwen, and Bunim (7) has indicated that aminotripeptidase activity may provide such a measure. The relatively high level of this enzyme in synovial effusions of patients with rheumatoid arthritis was demonstrated, and it was shown also that a decrease in the concentration of the enzyme, following intra-articular injection of hydrocortisone, was associated with improvement in the clinical status of joints and with a rise in the viscosity of the synovial fluid.

The purpose of the present investigation was to compare the aminotripeptidase levels in effusions from patients with a variety of arthritic diseases, in order to determine whether there was a relationship between the enzyme level and the severity of the inflammatory process, "severe" in this connection implying a profound change in the synovial membrane, rather than an acute but transient effect. If there were such a relationship, it would presumably be possible to separate arthritides into two extreme classes with regard to enzyme level:

1. High level: Rheumatoid arthritis,-profound inflammation and destruction.

2. Low level: Degenerative joint disease,-essentially non-inflammatory.

It would be expected, further, that there would be an intermediate or third group, comprising such diseases as rheumatic fever, gonococcal arthritis (with sterile joint effusions), Reiter's syndrome and gout; but heterogeneity would be anticipated in this group because gout and gonococcal arthritis, for example, may be markedly destructive.

Other questions to be explored were:

1. The possible value of the enzyme level in differential diagnosis.

2. The relationship of enzyme level to the leucocyte count in the synovial effusion. 
3. The comparison of enzyme levels in the synovial fluid and the blood serum.

\section{METHODS}

A total of 98 patients were studied (all the available patients with effusions of the knee during the period of the investigation)-31 with rheumatoid arthritis of the peripheral type, 17 with acute rheumatic fever (all above 12 years of age), 11 with degenerative joint disease, 2 with traumatic arthritis, 5 with gonococcal arthritis (all effusions of the sterile type), 16 with gout, and 16 with miscellaneous arthritides. One hundred and twelve synovial fluid samples were analyzed for enzyme concentration.

All samples were aspirated from knee joints using ethyl chloride anesthesia, since it has been shown (8) that procaine is a potent inhibitor of aminotripeptidase. The fluids were promptly centrifuged at 3000 r.p.m. for 20 minutes. This procedure removed the cells entirely except in very viscous samples in which, however, the cell counts were uniformly low even before centrifugation.

Aminotripeptidase was determined in synovial fluid, and in a number of instances in the serum, by the titrimetric method of Grassmann and Heyde, using thymolphthalein as indicator (9) usually within several hours of aspiration, on centrifuged, unhemolyzed specimens of synovial fluid. The substrate was glycylglycylglycine (obtained from Hoffman LaRoche, Inc., Nutley, N. J.). One-half milliliter of synovial fluid, $1.5 \mathrm{ml}$. of $0.02 \mathrm{M}$ veronal buffer at $\mathrm{pH} 7.8$, and $0.5 \mathrm{ml}$. of $0.25 \mathrm{M}$ glycylglycylglycine solution, neutralized to $\mathrm{pH} 7.8$, were incubated in a shaking water bath at $37^{\circ} \mathrm{C}$. Two-tenth milliliter samples were removed from the mixture at intervals, and titrated with $0.015 \mathrm{~N}$ potassium hydroxide in 90 per cent ethanol, with five drops of thymolphthalein as indicator. Depending on the rate of hydrolysis, samples were removed at from 15 to 90 -minute intervals. Five points, obtained from duplicate measurements in each case, were plotted for each determination and the per cent hydrolysis per hour was calculated from the straight line plot so obtained. Repeated determinations showed no fall in tripeptidase activity of synovial fluid stored in the refrigerator over a period of weeks. Results are given as percentage hydrolysis of glycylglycylglycine per hour.

Total leucocyte counts were done immediately after aspiration on fluid diluted twenty times with saline, and differential counts were made on stained smears of the sediment in the usual manner. Relative viscosity was measured with an Ostwald viscosimeter.

\section{RESULTS}

\section{Preliminary impressions}

In Figure 1 the distribution of aminotripeptidase activity of the entire group of 112 samples is given according to disease. For five of the prin- cipal diseases these raw data showed the following ranges in enzyme level (per cent hydrolysis per hour; number of samples in parentheses): Degenerative joint disease $(13), 1.4$ to 6.9 ; rheumatic fever (17), 3.6 to 12.2 ; rheumatoid arthritis (42), 3.3 to 56.3 ; gonococcal arthritis (5), 5.7 to 13.0 ; gout (18), 3.3 to 46.2 .

The relatively low values observed in degenerative joint disease, rheumatic fever, gonococcal arthritis and most of the miscellaneous arthritides are in marked contrast to the relatively high and widely scattered values found in rheumatoid arthritis and, to a lesser extent, in gout.

Of eight values in the rheumatoid group falling below the 10 per cent level, three were obtained on effusions from patients with acute rheumatoid arthritis, two were from joints with osteoarthritic changes secondary to long-established rheumatoid arthritis, and two were from patients with juvenile rheumatoid arthritis. Of the latter, one patient was studied a year later and the aminotripeptidase activity had risen from 4.0 to 12.4 per cent.

In the miscellaneous group, the highest value, 42.0 per cent, was found in a patient with disseminated lupus erythematosus. The diagnosis was based on the findings of L.E. cells in the peripheral blood and evidence of renal disease; but the joints showed chronic deforming changes identical with those of rheumatoid arthritis.

\section{Analysis of data}

The main analyses were confined to cases with the following characteristics:

1. Those with dependable information regarding the duration of symptoms, prior to investigation, in the joint examined.

2. Those with a definite record that, during the period immediately preceding the investigation, no treatment (except analgesics in a few instances) had been administered.

\section{Those of age 18 and over.}

The numbers of patients whose data qualified for the analyses were: degenerative joint disease, 8; rheumatoid arthritis, 14; rheumatic fever, 6; gout, 13; gonococcal arthritis, 4; Reiters's syndrome, 3. Standard statistical methods (analysis of variance and covariance, regression, and correlation) were employed, and the 5 per cent level 

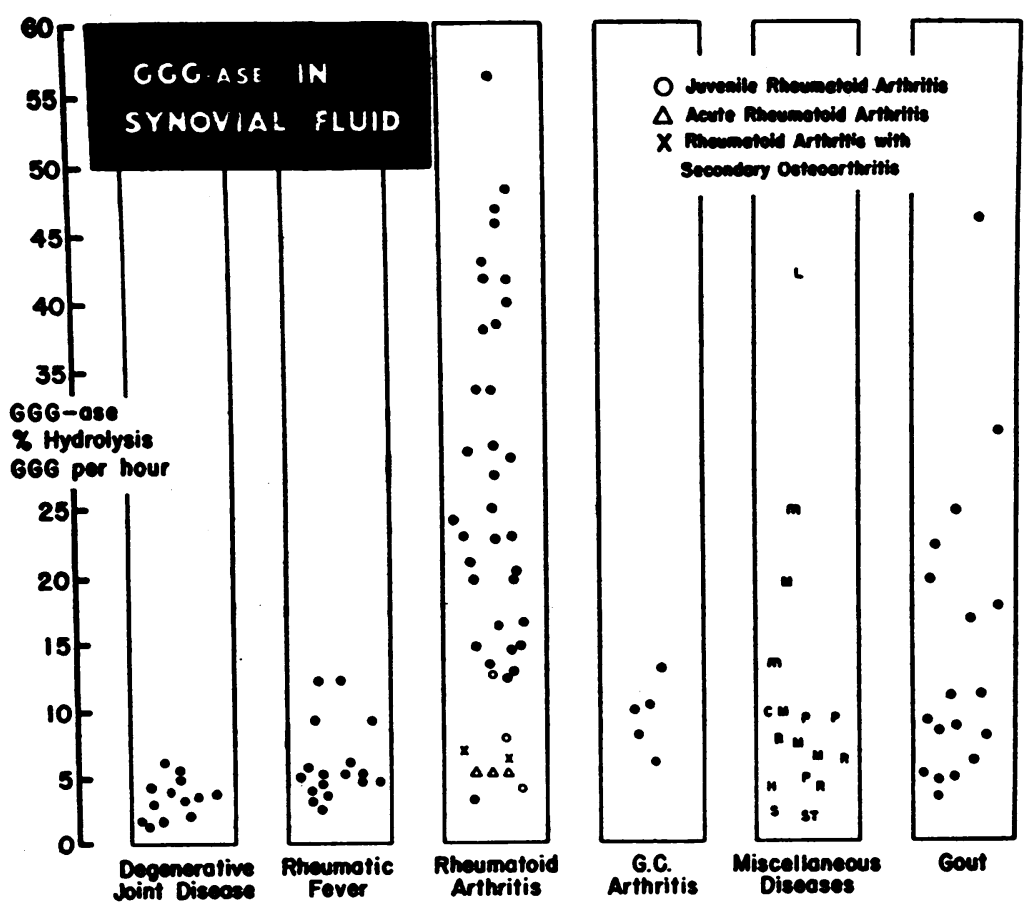

Fig. 1. Distribution of Aminotripeptidase Levels of the Synovial Fluid in a Number of Arthritic Diseases

$$
\begin{aligned}
\mathbf{L} & =\text { Disseminated lupus erythematosus } \\
\mathbf{M} & =\text { Marie-Strumpell disease } \\
\mathbf{m} & =\text { Meningococcemia (fluids sterile) } \\
\mathbf{C} & =\text { Coccidioidomycosis } \\
\mathbf{P} & =\text { Psoriatic arthropathy } \\
\mathbf{R} & =\text { Reiter's syndrome } \\
\mathbf{H} & =\text { Henoch-Schoenlein purpura } \\
\mathbf{S} & =\text { Subacute bacterial endocarditis } \\
\mathbf{S t} & =\text { Streptococcal pneumonia }
\end{aligned}
$$

was used as the minimum criterion for significance, i.e., $\mathrm{P}$ (the probability of occurrence if chance alone were operating) had to be less than 0.05 before a verdict of significance was given. (During the analysis it was found appropriate, for reasons that need not be discussed here, to express both the enzyme level and the duration of joint symptoms as logarithms, but the numerical values, given later, are in the original units, per cent hydrolysis per hour, obtained by reconversion). The results concerning the six diseases just enumerated (see Table I) can be summarized thus :

1. There was sufficient evidence of a positive correlation between enzyme level and the previous duration of symptoms in the joint aspirated to make it very likely that some of the variation in enzyme level between patients was associated with a difference in duration. This association could be due to one or both of two causes:

(a) Increase of enzyme concentration as the disease progressed.

(b) The longer duration of effusion in joints that were from the beginning more severely affected and, therefore, had a higher enzyme concentration throughout.

This second possibility could not be excluded, but the data did not suggest that it was a major factor, and, whatever the cause of the correlation, it was necessary to correct for it in order to obtain a reliable comparison between the mean enzyme levels in the various diseases.

2. There was no suggestion of sex or age difference in enzyme level, and, therefore, these characteristics were disregarded in further analysis. 
TABLE I

Mean levels of aminotripeptidase activity in synovial effusions

\begin{tabular}{|c|c|c|c|c|}
\hline \multirow[b]{2}{*}{ Disease } & \multicolumn{2}{|c|}{$\begin{array}{l}\text { Uncorrected for } \\
\text { duration of disease }\end{array}$} & \multicolumn{2}{|c|}{$\begin{array}{l}\text { Corrected for } \\
\text { duration of disease } \\
\text { as at } 10 \text { days* }\end{array}$} \\
\hline & $\begin{array}{c}\text { No. of } \\
\text { patients }\end{array}$ & $\begin{array}{c}\% \\
\text { Hydroly- } \\
\text { sis per } \\
\text { hour }\end{array}$ & $\begin{array}{c}\text { No. of } \\
\text { patients }\end{array}$ & $\begin{array}{c}\% \\
\text { Hydroly- } \\
\text { sis per } \\
\text { hour }\end{array}$ \\
\hline $\begin{array}{l}\text { Degenerative joint } \\
\text { disease } \\
\text { Rheumatoid arthritis } \\
\text { Rheumatic fever } \\
\text { Gonococcal arthritis } \\
\text { Gout } \\
\text { Reiter's syndrome }\end{array}$ & $\begin{array}{r}11 \\
31 \\
17 \\
5 \\
16 \\
3\end{array}$ & $\begin{array}{r}3.6 \\
24.1 \\
6.2 \\
9.6 \\
14.4 \\
6.0\end{array}$ & $\begin{array}{r}8 \\
14 \\
6 \\
4 \\
13 \\
3\end{array}$ & $\begin{array}{r}2.0 \\
14.7 \\
4.4 \\
7.0 \\
10.9 \\
6.2\end{array}$ \\
\hline
\end{tabular}

* In estimating the mean enzyme level with allowance for the effects of duration in symptoms, it was necessary to choose the same point in all diseases, and the tenth day was taken for illustration. This day was chosen because in each disease there were some effusions of shorter duration than 10 days and some longer.

3. When the relationships between enzyme level and previous duration of symptoms in the joint examined were expressed as linear regression coefficients (i.e., as the slopes of the best-fitting straight lines) no significant differences of slope were found among the six diseases.

4. In Figure 1 there appears to be a striking contrast in interpatient variation between such diseases as rheumatoid arthritis and rheumatic fever. Since such differences in variation are often correlated with differences in average values, the logarithms of the experimental values were used in comparing interpatient variation, and it was then found that this variation did not differ significantly among the diseases. The contrasts in Figure 1 can, therefore, be adequately accounted for by differences in general level in the different diseases-the higher the general or average level, the greater the interpatient variation.

5. Even after allowance for the enzyme-duration relationship (Table I), there was a highly significant difference in the mean enzyme levels among the six diseases ( $P$ far less than 0.001), and this agrees with the initial hypothesis regarding the grouping of diseases, as follows :

(a) Degenerative joint disease, with lowest enzyme level. (The two cases of traumatic arthritis, although insufficient to include in the full analysis, resembled degenerative joint disease in enzyme level.) (b) Rheumatoid arthritis, with highest enzyme level.

(c) An intermediate group (rheumatic fever, gonococcal arthritis, gout, Reiter's syndrome). It was further shown that the mean levels in these diseases differed significantly among themselves ( $P$ less than 0.05).

\section{Comparison of enzyme levels in synovial fluid and serum}

In 31 patients, determinations of the enzyme level in the serum were made at the same time as in the joint effusions. The data were not analyzed extensively because the salient features were clearly discernible. In the six patients with rheumatic fever, extreme values for synovial fluid were accompanied by extreme values for serum: 2.6 per cent in synovial fluid (2.3 per cent in serum) ; 12.2 per cent in fluid (8.0 per cent in serum). In three of the six, the serum levels were higher than the levels in the fluid, in the other three the difference was reversed. Two patients with degenerative joint disease gave the following readings in fluid and serum: 3.5 per cent (3.8 per cent in serum) ; 1.7 per cent ( 2.7 per cent in serum). These data suggest that in rheumatic fever and degenerative joint disease the synovial inflammation has little influence in increasing the tripeptidase level of the synovial fluid above the serum.

In the 14 patients with rheumatoid arthritis, the synovial fluid levels ranged from 5.3 per cent to 48.5 per cent; the serum levels from 2.4 per cent to 7.6 per cent. In all these patients the level in fluid exceeded the serum level, the contrasts ranging from 5.3 per cent in fluid (3.7 per cent in serum) to 46.0 per cent in fluid (3.0 per cent in serum).

In the nine patients with gout the fluid levels ranged from 3.3 per cent to 19.5 per cent, the serum levels from 1.7 per cent to 6.2 per cent; and the fluid levels exceeded the serum levels in all except one instance (fluid, 4.7 per cent, serum, 4.8 per cent).

Two noteworthy features in the above data are the general similarity of serum enzyme levels in the various diseases, and the discrepancy between serum levels and the levels in the synovial fluid in rheumatoid arthritis and gout, in contrast to the 
similarity of these levels in rheumatic fever and the two cases of degenerative joint disease.

\section{Relationship of enzyme level to leucocyte count}

In the experiments shown in Table II leucocytes and erythrocytes were completely removed from synovial fluid of ordinary viscosity by centrifugation, and in a number of other experiments it was shown that leucocytes were likewise successfully removed except in the very viscous fluids where the white counts and tripeptidase values were consistently low. It would follow from this that, at least in the usual range of viscosity, the tripeptidase activity that was measured was due largely or entirely to the enzyme dissolved in the synovial fluid. Moreover, as is shown by two of the samples in Table II, the presence of cells does not necessarily cause a marked increase in the enzyme level.

In the 45 patients whose data were subjected to detailed analysis there was only a moderate degree of correlation between the leucocyte counts and the enzyme levels, and the correlation did not differ significantly between the diseases. The average coefficients of correlation with enzyme level were +0.38 for the total white count and +0.43 for the polymorphonuclear count ( $P$ less than 0.02). The scatter diagrams (Figures 2 and 3 ) of total leucocyte and polymorphonuclear counts of freshly aspirated synovial fluid for the entire group of patients illustrate correlations of this magnitude.

\section{DISCUSSION}

\section{Classification of arthritides by characteristics of synovial fluids}

The aminotripeptidase levels have been shown to agree with the classification of diseases by severity of inflammation postulated at the outset: rheumatoid arthritis at the one extreme, degenerative joint disease (and traumatic arthritis) at the other, with an intermediate heterogeneous group, notably rheumatic fever, gout, gonococcal arthritis and Reiter's syndrome. It is of interest, however, to see how far the enzyme levels agree with a somewhat different classification, namely that of Ropes and Bauer (10) which is based on characteristics of the synovial fluid other than enzyme levels. In Group I of Ropes and Bauer are placed degenerative joint disease and traumatic

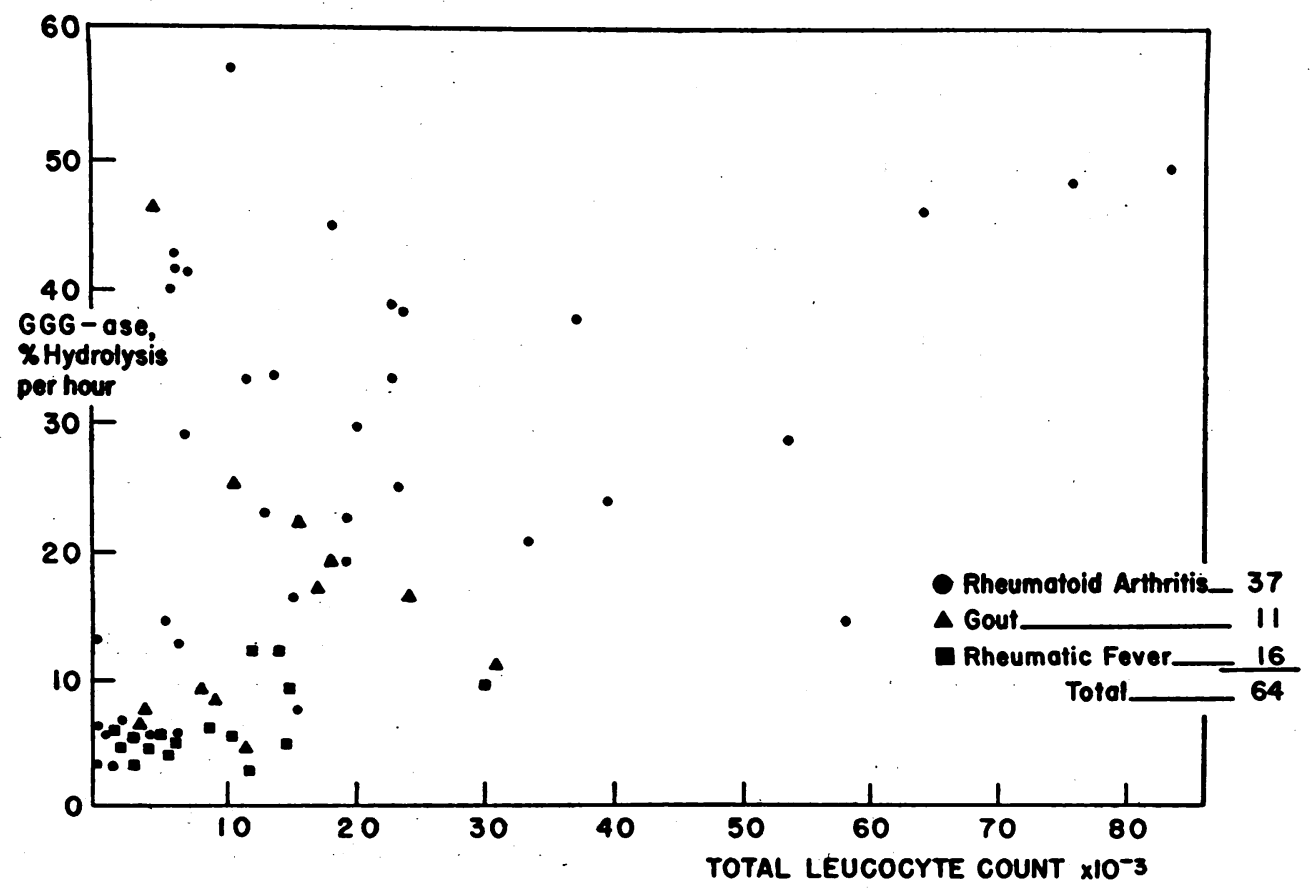

Fig. 2. Ammotripeptidase Levels Plotred Against Total Leucocyte Count of the Syrotial Fium 


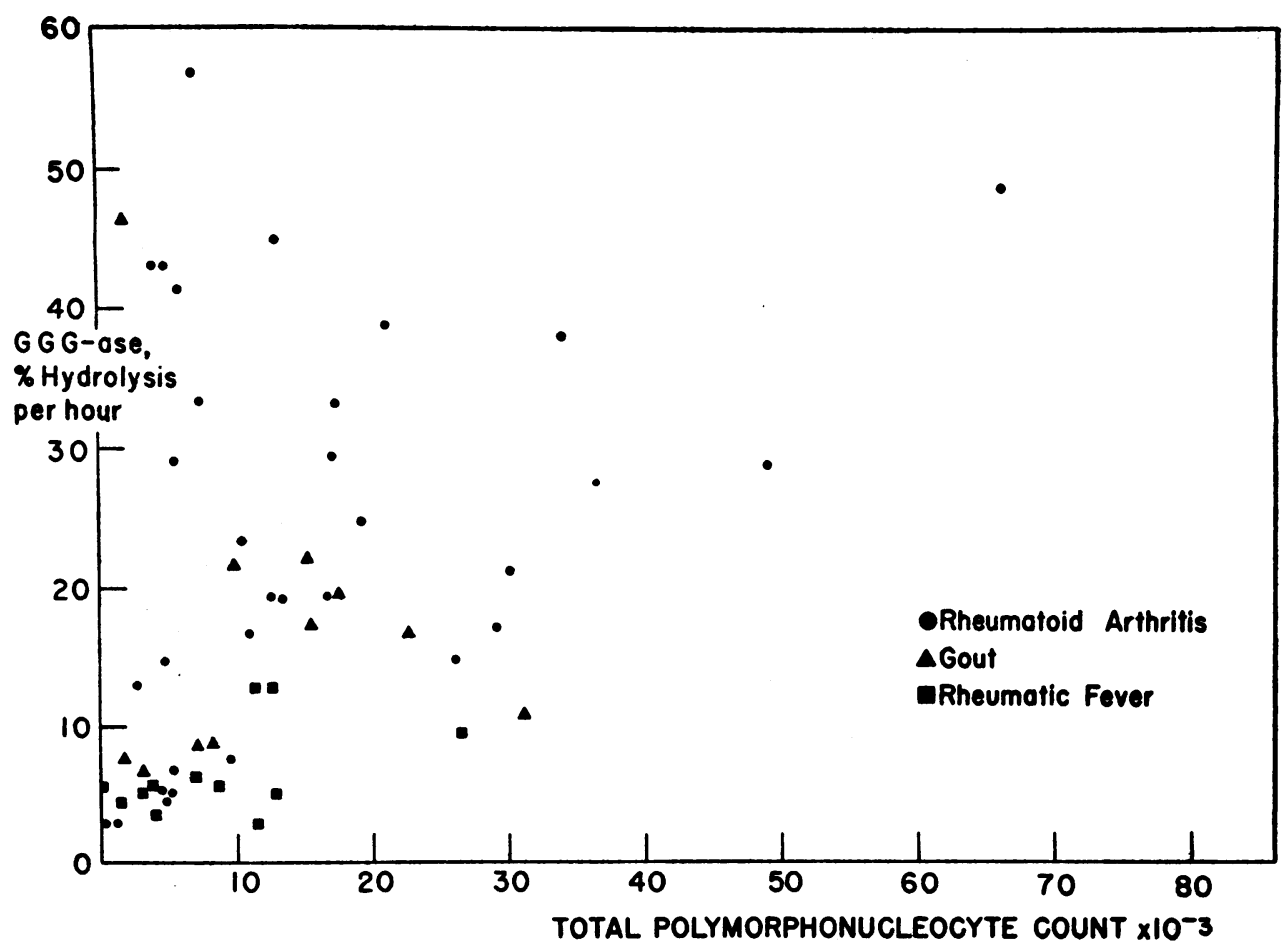

Fig. 3. Aminotripeptidase Levels Plottrd Against Polymorphonucleocyte Count of the Synovial Fruid

arthritis. In Group II occur rheumatoid arthritis, gonococcal arthritis and Reiter's syndrome. Fluids from rheumatic fever and gout are stated to resemble each of the two groups in various aspects.

The enzyme levels recorded in this report can be taken as confirming the separation of Group I. Although rheumatoid arthritis showed the highest mean level of enzyme activity of the diseases of Group II, the differences among the levels in rheumatoid arthritis, gonococcal arthritis and Reiter's syndrome were not significant. This again is in agreement with the Ropes and Bauer classification.

\section{Source of aminotripeptidase in cell-free synovial fluid.}

The large differences observed between the enzyme concentration in the blood and in the synovial fluid in many patients suggest that the increment is released from the synovial membrane. The high values observed in patients with chronic rheumatoid arthritis and the relatively low values in the presence of degenerative joint disease sug- gest that the increase is dependent on the presence of an inflammatory reaction in the synovial membrane. It appears evident, however, that the enzyme concentration does not mirror the acuteness of the inflammatory reaction as observed clinically, because relatively low levels were found in the effusions of rheumatic fever. The arthritis of that disease, although it may be very acute, produces no permanent tissue injury and usually disappears within a few days from any given joint.

It would be reasonable to suppose that a steady concentration of tripeptidase is maintained as a result of a balance between 1) a process of continuous degradation of leucocytes, and perhaps of connective tissue cells, on the surface of the synovial membrane or in the synovial fluid itself, and 2) the removal of the enzyme via the capillaries or lymphatics. The correlation between enzyme levels and leucocyte counts does not give a direct clue to the source of the enzyme. The data in Table II, however, indicate that the leucocytes suspended in the fluid at the time of aspiration are not the source, but that the enzyme must have been released prior to the aspiration. 
TABLE II

Cell counts and aminotripeptidase activity of centrifuged and uncentrifuged specimens of symovial fluid

\begin{tabular}{|c|c|c|c|c|c|}
\hline \multirow[b]{2}{*}{ Patient } & \multirow[b]{2}{*}{ Sample } & \multirow{2}{*}{$\begin{array}{l}\text { Relative } \\
\text { viscosity }\end{array}$} & \multicolumn{2}{|c|}{$\begin{array}{l}\text { Cell count } \\
\text { per } \mathbf{m m}^{\mathbf{2}}\end{array}$} & \multirow{2}{*}{$\begin{array}{c}\text { Aminotri } \\
\text { peptidas } \\
\text { activity } \\
\% \text { hy- } \\
\text { drolysis } \\
\text { per hour }\end{array}$} \\
\hline & & & RBC & WBC & \\
\hline D. K. & $\begin{array}{l}\text { Uncent. } \\
\text { Cent. }\end{array}$ & 二 & $\begin{array}{c}14,500 \\
0\end{array}$ & $\begin{array}{c}8,700 \\
0\end{array}$ & $\begin{array}{l}11.6 \\
10.5\end{array}$ \\
\hline $\begin{array}{c}\text { M. F. } \\
\text { (Right knee) }\end{array}$ & $\begin{array}{l}\text { Uncent. } \\
\text { Cent. }\end{array}$ & $\overline{6.5}$ & $\begin{array}{c}25,700 \\
0\end{array}$ & $\begin{array}{c}10,950 \\
0\end{array}$ & $\begin{array}{l}37.6 \\
36.5\end{array}$ \\
\hline $\begin{array}{l}\text { M. F. } \\
\text { (Left knee) }\end{array}$ & $\begin{array}{l}\text { Uncent. } \\
\text { Cent. }\end{array}$ & $\overline{8.8}$ & $\begin{array}{c}22,600 \\
0\end{array}$ & $\begin{array}{c}9,300 \\
0\end{array}$ & $\begin{array}{l}36.7 \\
30.5\end{array}$ \\
\hline D. L. & $\begin{array}{l}\text { Uncent. } \\
\text { Cent. }\end{array}$ & $\overline{4.7}$ & $\begin{array}{c}94,000 \\
0\end{array}$ & $\begin{array}{c}25,300 \\
0\end{array}$ & $\begin{array}{l}79.0 \\
49.0\end{array}$ \\
\hline
\end{tabular}

\section{Practical application of enzyme determinations}

As with other laboratory indices of the synovial fluid, there is an overlapping of enzyme values in the different diseases (Figure 1) which renders definitive diagnosis from the synovial fluid difficult. Values above 6.9 per cent, however, were not seen in degenerative joint disease, nor were values above 12.2 per cent found in rheumatic fever. Since approximately three-fourths of the patients with rheumatoid arthritis had effusions with peptidase activity that was higher than these figures, it would appear that elevation of tripeptidase above 12 per cent would help to differentiate rheumatoid arthritis from the other two. The relationship between enzyme level and duration of symptoms suggests that if a sufficiently large body of data were accumulated with an adjustment for duration of symptoms, diagnostic standards of some value might be derived.

As already mentioned, the aminotripeptidase activity of synovial effusions has been useful in following the status of the synovial fluid during intra-articular therapy with hydrocortisone (7), and the fall in enzyme content has corresponded closely with clinical improvement.

The stability of the enzyme in the synovial fluid offers an important advantage over other tests, since the determination can be carried out several weeks after the aspiration.

The very moderate degree of correlation between enzyme level and leucocyte count shows that the count would be of little value in estimating the enzyme level.
Finally, it should be pointed out that the possible utility of aminotripeptidase content in relation to assessment of inflammation is not restricted to synovial fluid. The authors have demonstrated activity of the same enzyme in empyema fluid and in purulent sputum, and it is likely that it may be found in almost any effusion associated with inflammation.

\section{SUMMARY}

1. Using glycylglycylglycine as substrate, the aminotripeptidase content of synovial effusions was measured in 98 patients with a wide variety of arthritic diseases.

2. Arthritides were grouped according to the severity of the inflammatory process in three classes : two extremes-degenerative joint disease (non-inflammatory) and rheumatoid arthritis (profound inflammation); and an intermediate group-rheumatic fever, gonococcal arthritis (with sterile effusions), Reiter's syndrome and gout. The three groups differed significantly in mean enzyme level, with the lowest values in degenerative joint disease and the highest in rheumatoid arthritis. The levels in the intermediate group, also, differed significantly, the highest level being found in gout.

3. The enzyme concentration in various diseases was positively correlated with the prior duration of symptoms in the joint investigated.

4. It is concluded that the aminotripeptidase content of synovial fluid is an index of the status of synovial inflammation, of value in following the progress of disease, and probably in diagnosis. It is suggested, also, that the aminotripeptidase content of other types of pathological effusions may serve as a useful measure of the inflammatory reaction in the tissues enclosing these effusions.

\section{REFERENCES}

1. Ellis, D., and Fruton, J. S., On the proteolytic enzymes of animal tissues. IX. Calf thymus tripeptidase. J. Biol. Chem., 1951, 191, 153.

2. Smith, E. L., The peptidases of skeletal, heart and uterine muscle. J. Biol. Chem., 1948, 173, 553.

3. Grassmann, W., and Heyde, W., Zur Kenntnis der Peptidasen des Blutserums. Vierte Abhandlung über Enzyme der Leukocyten in der von R. Willstätter und Mitarbeitern begonnenen Untersuchungsreihe. Ztschr. f. physiol. Chem., 1930, 188, 69. 
4. Barber, V. T., Stern, K., Askonas, B. A., and Cullen, A. M, Peptidases in human serum. Proc. Soc. Exper. Biol. \& Med., 1948, 67, 421.

5. Stern, K., Cullen, A. M., and Barber, V. T., Peptidase activity in human serum following bone fracture. J. Clin. Invest., 1949, 28, 419.

6. Schwartz, T. B., and Engel, F. L., Effect of adrenocorticotropic hormone and cortisone therapy on human plasma aminopeptidase activity. Proc. Soc. Exper. Biol. \& Med., 1950, 74, 82.

7. Ziff, M., Scull, E., Ford, D., McEwen, C., and Bunim J. J., Effects in rheumatoid arthritis of hydrocortisone and cortisone injected intraarticularly. Arch. Int. Med., 1952, 90, 774.

8. Ziff, M., and Smith, A. A., Inhibition of aminotripeptidase. Proc. Soc. Exper. Biol. \& Med., 1952, 80, 761.

9. Grassmann, W., and Heyde, W., Alkalimetrische Mikrobestimmung der Aminosaüren und Peptide. Ztschr. f. physiol. Chem., 1929, 183, 32.

10. Ropes, M., and Bauer, W., Synovial Changes in Joint Disease. Cambridge, Mass., Harvard University Press, 1953. 